\title{
The Plight of Islam in Europe
}

\section{John Horvath}

With the cold war officially "over," political scientists are busy setting the stage for the next pattern of conflict. Cold war ideology, best described as "a perpetual war for perpetual peace," has left an unexpected vacuum in world politics. With the post-cold war world order more unstable and dangerous than at any time since the end of the Second World War, many in the West find themselves struggling with an identity crisis. The golden age that was to arise from the defeat of communism has not come-on either side of the Iron Curtain - and prospects for world peace are more unlikely now than at any time during the cold war. In order to come to terms with this bankruptcy of present-day foreign policy, western society has begun to search for pariahs. As Kunstler observes, "it seems that the American public perennially needs identifiable villains to stimulate its gastric juices."' Consequently, Islam and Muslims have become the latest target.

Unlike previous enemies and opponents, which were based on nation-states and stimulated through nationalism and calls for patriotism, today's "evil empire" is based on civilizations and fueled by racism. According to Huntington, "the fault lines between civilizations will be the battle lines of the future." Hence Islam is seen as a distinct threat. The cultural fault lines between Islamic civilization and other civilizations around the world, from the Balkans and the bulge of Africa to Central Asia, are considered the most violent and unstable areas on earth. In Huntington's words, "Islam has bloody borders." "Such a view of Islam and Islamic civilization as something cancerous to global stability is a perfect replacement for the former enemy and its ideology: the ex-Soviet Union and communism. Once again, the American (and western) military-industrial complex can justify the continued need to produce arms while "defense" budgets continue to divert monies from social expenditures.

In Europe, as elsewhere, there is a basic misunderstanding of what Islam is and represents. Stereotypes of "Muslim terrorists" have permeated society. Anyone with a beard and/or a dark complexion is often treated as suspect. Muslims are generally seen as fanatics, worshipping the likes of Ayatollah Khomeini and Saddam Hussein and wanting nothing more in life than to kill Salman Rushdie. While many westerners consider Muslims to be fundamentalists, Muslims can view westerners as being just as funda- 
mentalist. In France, the minister of education, François Bayrou, introduced a ban on Muslim girls wearing the chador to school on the grounds that "it violates the tradition of secular education." Such ignorance and fundamentalism in western societies create a dilemma for many Muslims in Europe: How far are they willing to pursue social integration? Some feel that they must hide their Islamic identity if they want to succeed. As economic pressures force Muslims to throw away their traditions in order to get jobs, it is feared that Islam in Europe will soon vanish.

More liberal-minded Europeans try to explain the increased hostility toward Islam as a recent phenomenon due mainly to the sudden influx of migrants to Europe. Thus, some argue that European society needs time to adapt to the newcomers. But Islam is not new to Europe, for Muslims have always had a foothold in Europe, both in the East (the Balkans and, for a short period of time, much of modern Hungary) and the West (the Basque region of Spain). In most European countries, Islamic penetration during the fifteenth and sixteenth centuries through the expansion of the Ottoman Empire is regarded as a dark moment in European history. In Hungary, for instance, all Hungarians view the century and a half of Turkish occupation as a national tragedy. And yet it was during this same period that paprika, the nation's staple (and to some extent national identity), as well as many of Budapest's famed steam baths were introduced.

Not only has Islam been a part of Europe's past, but Muslims have also been an integral part of its present. They own and work in most of the corner shops seen throughout the capital cities of Europe. Many are intellectuals and scientists who have made, and continue to make, significant contributions to European academic life. Moreover, most Muslims who came to Europe already possessed substantial knowledge about its history and culture, for it is inherent in Islam that Muslims study other peoples, be tolerant toward other cultures, and engage in cultural exchanges.

\section{A New Paradigm}

Apart from the West's basic misunderstanding and ignorance of Islam, the idea of international affairs as nothing more than titanic clashes of global dimensions between power blocs shows how the western world has not yet healed itself from the scars of the Second World War-a war caused, ironically, by western civilization.

During the cold war, the world was divided in terms of political and economic systems. Islam, communism, and the Soviet Union were seen as alien. This process of cultural misunderstanding has existed for centuries. Earlier mapmakers drew ridiculous monsters on "unknown lands," which at one time made up a greater part of the world. The cold war continued this tradition, for the "unknown land"- then the Soviet Union and now the Islamic world-was portrayed as the enemy. However, the assumption that the world operated (and still does) in terms of allied power blocs, 
which was reinforced through the confrontational image of the superpowers, was artificial, for both sides collaborated with each other on most international issues. Like opposition parties that rally together in times of national crisis, so too did both superpowers when the cold war world order was under threat. This is why the United States was the most cautious of nations in dealing with the fall of communism in eastern Europe. For example, it was one of the last countries to recognize the independent nation of Slovenia and Croatia, which heralded the dissolution of Yugoslavia.

Along these lines, the cold war can be seen as a cover for a war against the third world to which, incidentally, most Islamic nations belong. The symbiotic relationship between the United States and the Soviet Union was a means for exploiting the resources falling within their respective "spheres of influence." As Chomsky remarked during the Gulf War, these resources were imperialistically coveted by the West and the fact that they lay outside their territory was merely a "geographical accident."

What kept this geopolitical paradigm intact for the past fifty years was the muddled role of ideology. Defined as a set of ideas on which a political or economic system is based, ideology was considered an important aspect and integral part of the cold war. It was supposedly the glue that made the Soviet Union a strong hegemonic power and held communist-ruled eastern Europe together. Communist ideology, which was believed to allude to the universalistic ideas of Marx and Lenin, was exploited by communist states for propaganda purposes. In the West, ideology was seen as a dangerous form of deception, for it infringed on national policy without regard for the workings of world politics and international relations.

However, ideology as such was not so important in communist society. Instead, it was valued for its role as legitimizing communism's monopoly on power and Soviet colonization. Cold war aims, as a result, were modified by political considerations so that they became both an instrument and an expression of political policy. No decision could have been made on major policy issues without a priori recognition of political relations. Pure ideology, therefore, was not allowed to determine the course and conduct of the cold war.

Although this geopolitical paradigm has now been left to the pages of history, the basic foundation remains intact. Islam and the "clash of civilizations" have simply replaced communism and the cold war. The major difference, however, is that there is no symbiosis between Islam and the West. Rather, the neo-cold war view of the "clash of civilizations" calls for direct confrontation and justifies itself via the concept of a "world community," a euphemism that seeks to legitimize the policing actions of the West. A prime example is the abuse and misuse of environmentalist issues. Now that western nations have fully industrialized their economies and societies, they are in the position to prevent others from doing so under the guise of environmental protection. Though the United States and western countries were free to pollute and rape their- 
and others'-environments in the name of the industrial-technological revolution, they have now secured their monopoly on development by restricting it elsewhere. Trade sanctions and World Bank and International Monetary Fund (IMF) conditions have been used repeatedly as a means of intervention.

In essence, what the "clash of civilizations" hypothesis demonstrates is that the economical subjugation of nonwestern countries, the classic North-South dichotomy, is still prevalent. Many conflicts remain economically based and have nothing to do with a clash of cultural identities. Neo-cold war warriors such as Huntington have warned of a "ConfucianIslamic connection" that has emerged to challenge western interests, values, and power. The Confucian element (China) has been added to this hypothesis because of its enormous economic potential. Throughout eastern and central Europe, approximately seven hundred thousand Chinese "suitcase" traders are involved in legal and semilegal activities. Meanwhile, direct American-Chinese trade is raising concern in the West of an influx of Chinese products, which gives rise to problems associated with unfair trading practices and unbalanced commercial relations.

Yet, in effect, what is happening is that the global economy's decline has proven that the market-oriented approach to economics is inadequate. Such global institutions of economic management as the IMF and the World Bank have been unable to manage the global economy. Consequently, domestic economies are unable to bear the burden of social problems arising from unrealized expectations.

Until now, international trade in the post-cold war world order has been mainly a one-sided affair consisting of an influx of predatory capital and cheap western goods into the global market. The unceasing drive of multinational corporations to increase their profits by reducing production costs has blurred the concept of international trade through transfers of capital between their numerous divisions located in different countries. Plants have been established in countries where products can be mined, grown, processed, or manufactured at the lowest cost. With the rise of Chinese economic power, this "corporate mercantilism" of the West is threatened.

Hence, the neoimperialistic notion of a clash of civilizations is an indication that western civilization is in its death throes. Huntington's shortterm recommendation for the West- "to promote greater cooperation and unity with its own civilization"s-is a prelude to collapse. In A Study of History, Arnold Toynbee demonstrates that in all past civilizations the achievement of unity marked the beginning of the end. Moreover, a brief "flowering" period in the arts further signaled a civilization's inevitable decline and fall. Western civilization has already experienced its flowering period and its concern for unity, both politically in Europe with the European Community (EC) and economically in North America with the North American Free Trade Zone (NAFTA), is further evidence of its advanced state of decline. 
For Islam, however, the decline of western civilization poses a danger. Having convinced themselves of a coming clash of civilizations, neo-cold war warriors are determined to stave off the inevitable, thereby threatening to bring others with them down the road to ruin.

\section{Endnotes}

1. William Kunstler, "A Society in Search of Pariahs Alights on Muslims-For Now," Toward Freedom 43, no. 1 (February 1994): 23.

2. Samuel P. Huntington, "The Clash of Civilizations," Foreign Affairs 72, no. 3 (Summer 1993): 22-49: 23.

3. Ibid., 35.

4. Noam Chomsky, "West Fighting to Protect World Order," The Independent 1. no. 330 (19 January 1991): 8 .

5. Huntington, Clash, 49. 